\title{
Requirement of clathrin heavy chain for p53-mediated transcription
}

\author{
Masato Enari, ${ }^{1,2,4}$ Kazuji Ohmori, ${ }^{1,2,4}$ Issay Kitabayashi, ${ }^{3}$ and Yoichi Taya ${ }^{1,2,5}$ \\ ${ }^{1}$ Radiobiology Division, ${ }^{2}$ Solution-Oriented Research for Science and Technology (SORST), Japan Science and Technology \\ Agency (JST), ${ }^{3}$ Molecular Oncology Division at the National Cancer Center Research Institute, Tsukiji 5-1-1, Chuo-ku, \\ Tokyo 104-0045, Japan
}

\begin{abstract}
The p53 protein is a transcription factor that activates various genes responsible for growth arrest and/or apoptosis in response to DNA damage. Here, we report that clathrin heavy chain (CHC) binds to p53 and contributes to p53-mediated transcription. $\mathrm{CHC}$ is known to be a cytosolic protein that functions as a vesicle transporter. We found, however, that $\mathrm{CHC}$ exists not only in cytosol but also in nuclei. $\mathrm{CHC}$ expression enhances p53-dependent transactivation, whereas the reduction of CHC expression by RNA interference (RNAi) attenuates its transcriptional activity. Moreover, $\mathrm{CHC}$ binds to the p53-responsive promoter in vivo and stabilizes p53-p300 interaction to promote p53-mediated transctiption. Thus, nuclear $\mathrm{CHC}$ is required for the transactivation of p53 target genes and plays a distinct role from clathrin-mediated endocytosis.
\end{abstract}

[Keywords: p53; clathrin; p300; apoptosis; p53AIP1]

Supplemental material is available at www.genesdev.org.

Received October 5, 2005; revised version accepted February 27, 2006.

The p53 gene, in which mutations have been found in $>50 \%$ of human cancers, encodes a protein that plays an important role in preventing tumorigenesis (Levine 1997; Prives and Hall 1999; Vogelstein et al. 2000; Vousden and Lu 2002; Bourdon et al. 2003; Oren 2003). The function of p53 to induce growth arrest and apoptosis is tightly associated with tumor progression. p53 functions as a regulator of various phenomena including transcriptional activation for cell cycle arrest and apoptosis (Bourdon et al. 2003; Oren 2003), centrosome duplication (Tarapore and Fukasawa 2002), homologous recombination (Linke et al. 2003), nucleotide excision repair (Seo et al. 2002), and transcription-independent apoptosis (Mihara et al. 2003). It is thought that transcriptional regulation by p53 is most important for the prevention of tumorigenesis because most mutations of p53 in tumor cells are located in the central DNA-binding domain (Hollstein et al. 1991).

In growing cells, the expression level of p53 protein is kept low as a latent form by a mechanism involving the ubiquitin/proteasome-mediated degradation pathway. Mdm-2 oncoprotein is an E3 ubiquitin ligase for p53 and binds to the $\mathrm{N}$ terminus of p53 to degrade p53 (Honda et al. 1997). However, following various genotoxic stresses, p53 dissociates from Mdm-2 through post-translational

\footnotetext{
${ }^{4}$ These authors contributed equally to this work.

${ }^{5}$ Corresponding author.

E-MAIL ytaya@gan2.res.ncc.go.jp; FAX 081-3-5565-0727.

Article published online ahead of print. Article and publication date are

at http://www.genesdev.org/cgi/doi/10.1101/gad.1381906.
}

modification including phosphorylation at Ser15 and Ser20, and accumulates in cells (Shieh et al. 1997, 1999; Siliciano et al. 1997). The subsequent phosphorylation and acetylation of p53 lead to the activation of sequencespecific DNA binding and transcription of various genes responsible for DNA repair (p53R2 and GADD45), growth arrest (p21 waf1), and apoptosis (Bax, Noxa, Puma, and p53AIP1) (Levine 1997; Prives and Hall 1999; Vousden and Lu 2002; Bourdon et al. 2003). We have previously shown that Ser46 in p53 is phosphorylated following DNA damage and that this phosphorylation contributes to the transactivation of p53 target genes, in particular, mitochondrial proapoptogenic factor p53AIP1 (K. Oda et al. 2000).

Although it has been reported that many p53-associated proteins including histone acetyl transferase p300/ $\mathrm{CBP}$, an apoptosis-stimulating protein of p53 (ASPP), TATA-binding protein (TBP), TBP-associated factors (TAFs), Sp1, high mobility group-1 (HMG-1), and the p300 coactivator JMY participate in p53-mediated transcription (Prives and Hall 1999; Ljungman 2000; Samuels-Lev et al. 2001), the detailed mechanisms remain unclear due to the complexity and difficulty of obtaining the p53-transcriptional machinery as a stable complex. Presumably, their interaction contributing to dynamic transcriptional processes may be transient and the complex dissociates rapidly.

It is known that some polymorphic and artificial mutations enhance the stability of protein-protein interaction and affect cellular functions (Marin et al. 2000). While investigating the role of p53 phosphorylation at 
Ser46, we found a bladder carcinoma bearing a p53 mutation at Ser46 to Phe by database search (Taylor et al. 1996). Unexpectedly, this substitution strongly enhanced the transactivation of p53AIP1 promoter, although this mutation was found in tumor cells. We explored p53-binding proteins whose affinity was altered by this substitution and identified clathrin heavy chain (CHC). Clathrin is known to be a cytosolic protein that functions as a vesicle transporter and is required for the down-regulation of certain ligand-induced receptors including epidermal growth factor receptor (EGF-R) as well as the uptake of nutrients and for the protein sorting at the trans-Golgi network during protein secretion (Kirchhausen 2000; Conner and Schmid 2003). In addition, it has been recently shown that clathrin is also essential for mitosis (Royle et al. 2005).

Here, we found that $\mathrm{CHC}$ exists not only in cytosol but also in nuclei, and is required for the transactivation of p53 target genes. Moreover, CHC binds to the p53responsive promoter in vivo and stabilizes p53-p300 interaction to promote p53-mediated transcription. Our data demonstrate that nuclear $\mathrm{CHC}$ plays a distinct role from clathrin-mediated endocytosis, and thus, CHC works as a dual functional protein similar to $\beta$-catenin (Behrens et al. 1996) and $\beta$-actin (Rando et al. 2000; Olave et al. 2002).

\section{Results}

A p53 mutant substituted at Ser46 to Phe enhances p53-mediated transcriptional activity

While investigating p53 phosphorylation at Ser46, we noted a p53 mutant bearing Ser-to-Phe substitution at codon 46 (p53S46F) in human bladder carcinoma (Taylor et al. 1996). (Later, we noticed that this bladder tumor from an arylamine-exposed worker contained a splice site error at intron 4-exon 5 junction in addition to S46F mutation, and probably the p53 of this patient was inactivated by this splice site error.) We first examined the effect of this p53 mutation on the transcriptional activity using p53AIP1 promoter (K. Oda et al. 2000). When wild-type p53 (p53wt) or p53S46F was expressed in p53null cells, p53S46F increased the transactivation of p53AIP1 promoter up to twice as much as that of $\mathrm{p} 53 \mathrm{wt}$ (Fig. 1A), although the protein level of p53wt was significantly higher than that of p53S46F (Supplementary Fig. S1). A Ser-to-Asp substitution of p53 at codon 46 had little or no effect on the transactivation of p53AIP1 promoter, whereas a Ser-to-Ala substitution decreased transactivation up to $60 \%$; a p53 mutant lacking amino acids of the 44-63 transcriptional activation domain had no ability to transactivate $p 53 A I P 1$ promoter (data not shown). We then confirmed the effect of Ser-to-Phe substitution of p53 on its transcriptional activity by monitoring the induction of endogenous p53 target genes. RTPCR experiments showed that the mRNA induction of p53-responsive genes by p53S46F gave higher values than that by p53wt, although the protein level of p53S46F was significantly lower than that of p53wt (Fig.
1B). Overexpression of p53 in H1299 cells (p53-null) induces apoptosis (K. Oda et al. 2000). We therefore examined whether p53S46F has the potential to induce apoptosis. p53S46F had higher apoptotic activity than p53wt, as judged by caspase-3/7 activation and TUNEL analysis, indicating that this substitution also enhances apoptotic activity (Fig. 1C).

\section{Identification of CHC as a p53-binding partner}

It is known that some polymorphic and artificial mutations enhance the stability of protein-protein interaction and affect cellular functions (Marin et al. 2000). Therefore, we explored p53-binding proteins whose affinity was altered by Ser-to-Phe substitution to clarify the mechanism by which this substitution enhances p53mediated transcriptional activity. Flag-tagged p53 was expressed in H1299 cells, immunoprecipitated with antiFlag antibody (M2)-conjugated agarose beads, and eluted with a competitive Flag peptide. Comparison of eluates between p53wt and p53S46F revealed a protein (p190) with a relative molecular weight of $\mathrm{Mr} 190,000$ that is tightly bound to p53S46F compared with p53wt (Fig. 2A). By mass spectrometric analysis, we identified this protein as $\mathrm{CHC}$ (Fig. 2A). We confirmed that this protein is $\mathrm{CHC}$ by immunoblotting with anti-CHC antibody (Fig. 2B). Interestingly, $\mathrm{CHC}$ also bound to p53wt with weak affinity, indicating that the interaction of p53 with $\mathrm{CHC}$ is stabilized by a Ser-to-Phe mutation of p53 at codon 46 . By using anti-CHC antibody, we next examined the interaction between endogenous p53 and CHC proteins. Immunoblot analysis showed that p53 was present in the immunoprecipitates from nuclear extracts of MCF-7 cells, but not in the control immunoprecipitates (Fig. $2 \mathrm{C})$. The interaction was strongly detected in cells subjected to genotoxic stress, whereas only slight enhancement was detected in cells treated with a proteasome inhibitor LLNL (Fig. 2C). These results indicate that p53 interacts with $\mathrm{CHC}$ in vivo and that $\mathrm{CHC}$ contributes to p53-mediated regulation in response to DNA damage.

\section{CHC exists not only in cytosol but also in nuclei}

$\mathrm{CHC}$ is known to play an important role in regulating endocytosis and protein sorting at the trans-Golgi network during secretion (Kirchhausen 2000; Conner and Schmid 2003). In endocytotic pathways, CHC interacts with clathrin light chain (CLC) through the C-terminal region of CHC (Liu et al. 1995). As shown in Figure 2A, however, no specific binding partner of p53S46F was visualized by silver staining except the $\mathrm{CHC}$ band. Indeed, CLC was not contained in the precipitates when p53 was immunoprecipitated (Fig. 2B), suggesting that p53-bound $\mathrm{CHC}$ has a different role from that acting in the endocytotic pathways. We next examined whether $\mathrm{CHC}$ is localized in nuclei. Immunohistochemical analysis revealed a very strong signal in the cytoplasm and weak fluorescence in nuclei (data not shown). To exclude the possibility that signals in the nuclei are due to halation 
A
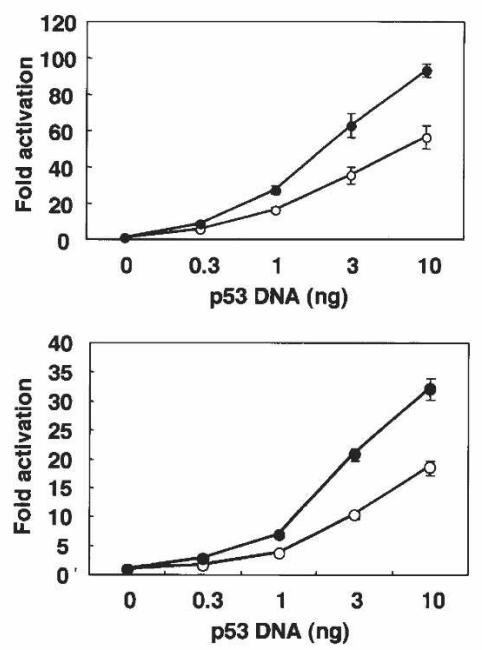

C

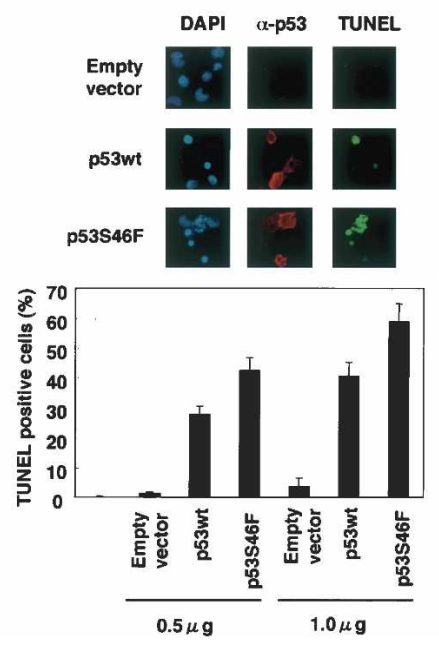

B

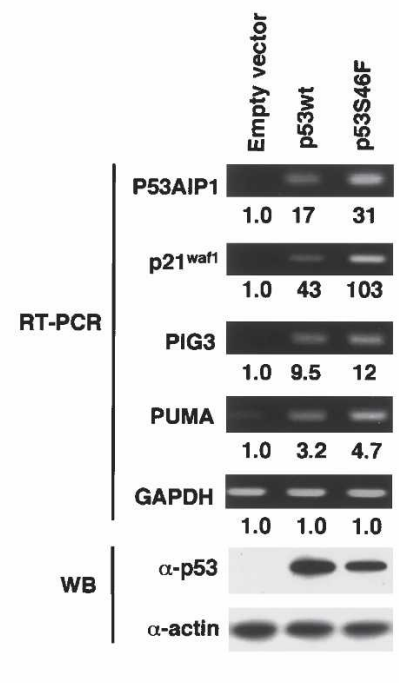

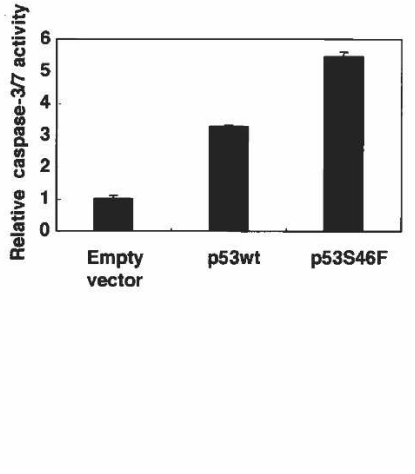

Figure 1. Enhancement of p53 activity by a Ser-to-Phe substitution of p53 at codon 46. (A) p53S46F mutant revealed increased transactivation of p53AIP1 promoter. Saos-2 (top) or H1299 (bottom) cells were transfected with various amounts of p53wt (open circles) or p53S46F (filled circles) in combination with $200 \mathrm{ng}$ of p53AIP1-luciferase reporter vector for p53AIP1 transactivation, and luciferase activity was measured at $24 \mathrm{~h}$ after transfection. (B) p53S46F mutant enhances the expression of endogenous p53 target genes. The expression level of transfected p53 is shown at the bottom. $(C)$ Apoptotic activity of p53 is enhanced by this substitution. The upper left panel shows representative photographs of H1299 cells in the TUNEL assay after p53 transfection. The percentage of apoptosis determined by TUNEL analysis (bottom left) and caspase-3/7 activity determined by the amounts of cleaved fluorogenic substrates (right) are shown. from cytoplasmic $\mathrm{CHC}$ fluorescence, nuclei were isolated from cells and fixed on a poly-L-lysine-coated slide. When they were stained with anti-CHC antibody, CHC as well as p53 was found in isolated nuclei (Fig. 3A). Moreover, biochemical fractionation revealed that a fraction of $\mathrm{CHC}(\sim 5 \%$ of total) was present in nuclear extracts (Fig. 3B). Furthermore, CHC localization in the nucleus was confirmed by immuno-electron microscopy using anti-CHC antibody (Fig. 3C).

\section{Mapping of the binding domain between p53 and $\mathrm{CHC}$}

To delineate the interaction domain of $\mathrm{CHC}$ and $\mathrm{p} 53$, in vitro binding assays were performed. A pull-down assay with glutathione-S-transferase (GST) fusion proteins showed that ${ }^{35} \mathrm{~S}$-labeled full-length $\mathrm{CHC}$ interacts with wild-type p53 (GST-p53wt) fused to GST, and that the $\mathrm{C}$-terminal region containing CLC-binding and trimer- ization domains is required for the interaction (Fig. 4A). These results suggest that the association of p53 with CHC may be exclusive to the CHC-CLC interaction, consistent with the fact that CLC is absent from nuclear CHC-p53 complex.

To map the binding domain of p53 to $\mathrm{CHC}$, we prepared various deletion mutants of p53 as GST fusion proteins and performed an in vitro binding assay using ${ }^{35}$ S-labeled CHC. Figure 4B shows that the C-terminal part of p53 was dispensable for the interaction with $\mathrm{CHC}_{\text {; }}$ the $\mathrm{N}$-terminal region was required for the association, consistent with the fact that it is essential for transactivation (Chen et al. 1996; Zhu et al. 1998). CHC has binding activity not only to the AD2 domain in which Ser46 is located, but also to AD1 and the Prolinerich (Pro) domain, and it appears that the Pro domain is most essential for the binding to $\mathrm{CHC}$, although the substitution of Ser46 to Phe enhances these associations. These data suggest that this interaction may not be re- 
Enari et al.

Figure 2. p53 interacts with CHC. (A) Silver staining of immunoprecipitates from cell lysates transfected with empty vector (lane 1), p53wt-Flag (lane 2), p53S46F-Flag (lane 3), and p53 444-63-Flag (lane 4). The p190 protein was identified as CHC by mass spectrometry. Five peptide sequences were obtained from mass spectrometry as shown on the right. (B) p53 binds to $\mathrm{CHC}$ but not CLC. The immunoprecipitates in $A$ were immunoblotted with the indicated antibodies. $(C) \mathrm{CHC}$ interacts with endogeneous p53. MCF-7 cells were treated with LLNL $(50 \mu \mathrm{M})$ for $4 \mathrm{~h}$ or with adriamycin $(3$ $\mu \mathrm{M}$ ) for $16 \mathrm{~h}$ The nuclear extracts were immunoprecipitated with anti-CHC antibody (X.22) and subjected to immunoblotting with anti-CHC antibody (clone 23; top) or anti-p53 antibody (DO-1; bottom).
A

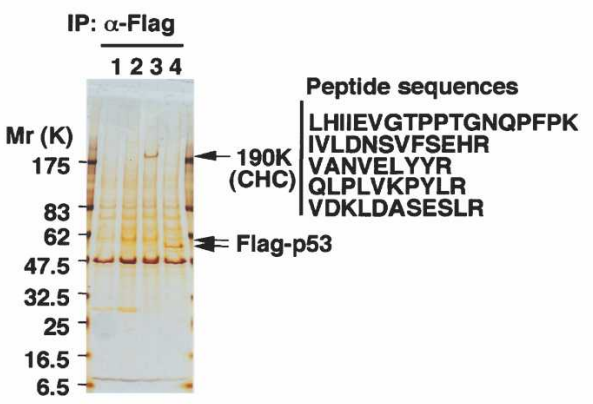

C

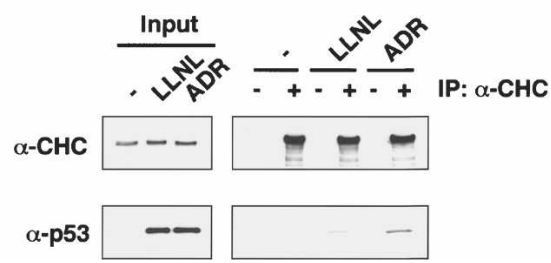

B

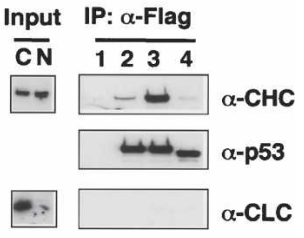

stricted only to the AD2 domain, but that both $\mathrm{AD} 1$ and Pro domains may also be required for the binding to CHC. Alternatively, another factor might be required for the interaction between p53 and $\mathrm{CHC}$ to modulate the binding affinity. The proline-rich domain of p53 (residues 64-92) is necessary for the induction of apoptosis, but not for cell growth arrest (Zhu et al. 1999). In contrast, our deletion mutant lacking the Pro domain (resi- dues 64-101) used in this experiment has neither apoptotic activity, the ability to induce cell cycle arrest, nor transcriptional activity (data not shown). Thus, nine residues (residues 93-101) of p53 are likely to be required for the transcription function for cell growth arrest. Presumably, the loss of binding of the p53 mutant lacking the Pro domain to $\mathrm{CHC}$ may be due to the deletion of residues $93-101$ of $\mathrm{p} 53$.
Figure 3. Some $\mathrm{CHC}$ is localized in the nuclei. $(A) \mathrm{Nu}-$ clei were isolated from MCF-7 cells; fixed on a poly-Llysine-coated slide chamber; and stained with control IgG (top), anti-CHC antibody (X.22; middle), or anti-p53 antibody (DO-1; bottom); followed by incubation with anti-mouse IgG antibody-conjugated AlexaFluor488 (green) or AlexaFluor594 (red). Nuclei were visualized by DAPI staining (blue; right). (B) CHC is present in the nuclear extracts. Nuclear (N) or cytosolic (C) extracts were prepared from MCF-7 cells. The extracts (equivalent to $4 \times 10^{4}$ cells for cytosolic extracts; to $8 \times 10^{5}$ cells for nuclear extracts) were analyzed by immunoblotting with specific antibodies against p53 (DO-1), $\mathrm{CHC}$ (clone 23), $\beta$-tubulin (referred to as a cytosolic protein) and TRAP150 (referred to as a nuclear protein). (C) Immuno-electron micrographs of CHC. MCF-7 cells were fixed with $4 \%$ paraformaldehyde plus $0.05 \%$ glutaraldehyde and thin sections were reacted with anti$\mathrm{CHC}$ antibody at $4^{\circ} \mathrm{C}$ overnight, followed by incubation with $10 \mathrm{~nm}$ of gold particle-conjugated secondary antibody. Arrows show CHC spots only in the nucleus, although many $\mathrm{CHC}$ spots were observed in the cytosol. (C) Cytosol; (N) nucleus. Bar, $200 \mathrm{~nm}$.
A

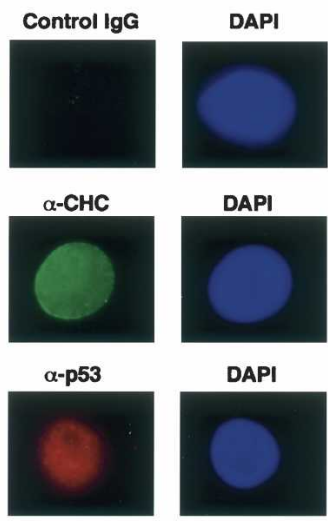

C

Control IgG

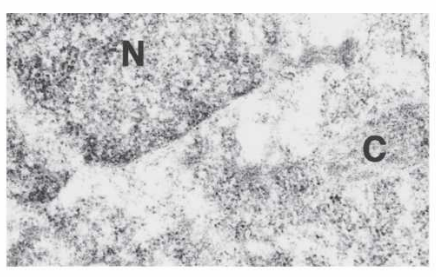

B

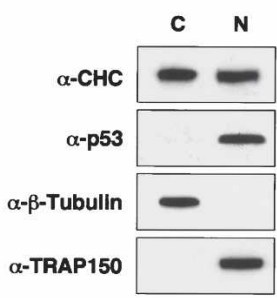

$\alpha-\mathrm{CHC}$

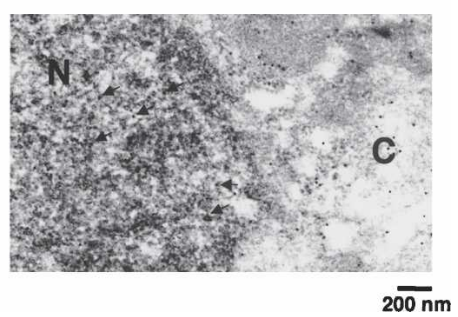


A
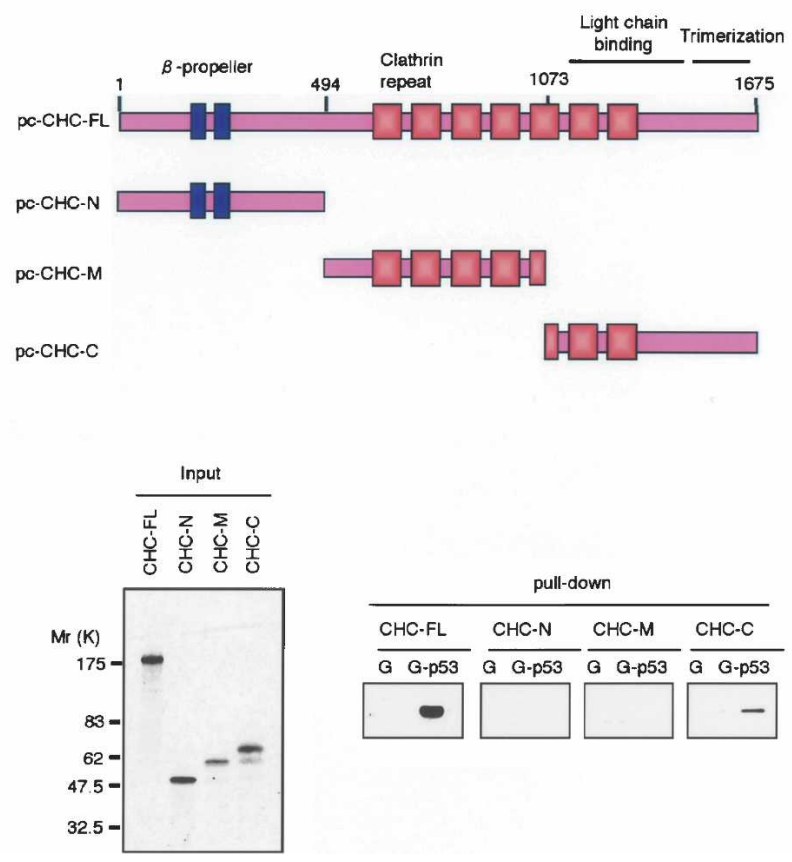

B
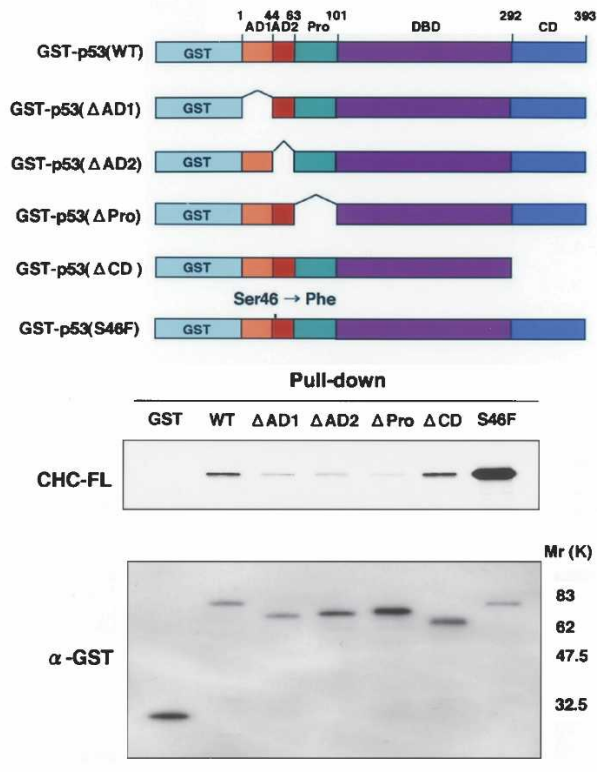

Figure 4. Domain analysis of the interaction between p53 and CHC. (A) Delineation of the domain in CHC that mediates association with $\mathrm{p} 53$ in the in vitro binding assay. (Top $)^{35}$ S-labeled, in vitro translated $\mathrm{CHC}$ and deletion derivatives were used for the binding to GST or GST-p53wt beads. (Bottom) The C-terminal region of CHC is required for the association with p53. (B) Delineation of CHC-binding domains in p53 by in vitro binding assay. (Top) p53 and deletion derivatives were produced as GST fusion proteins and used for the binding to ${ }^{35} \mathrm{~S}$-labeled, in vitro translated CHC. (Middle) $\mathrm{N}$-terminal transactivation domains of p53 are necessary for binding to CHC. GST fusion proteins were visualized by immunoblotting with anti-GST antibody. (AD) Activation domain; (Pro) proline-rich domain; (DBD) DNA-binding domain; (CD) C-terminal domain.

Next, we examined whether tumor-derived mutants of p53 are associated with $\mathrm{CHC}$. The p53 mutants bearing a mutation of Arg to His at codon 175 (p53R175H) and a mutation of Arg to Trp at codon 248 (p53R248W), which cannot bind to $\mathrm{p} 53$-responsive promoter, were prepared as GST fusion proteins and used for GST pull-down assay. As shown in Supplementary Figure S2, tumor-derived mutants of $\mathrm{p} 53$ were able to associate with $\mathrm{CHC}$, suggesting that the sequence-specific DNA-binding activity of p53 is not required for the association with CHC.

\section{CHC is required for the transactivation of p53-responsive promoters}

To assess whether $\mathrm{CHC}$ is involved in p53-mediated transcription, we carried out a reporter assay using p53AIP1 promoter as above. When CHC was transfected with p53 in $\mathrm{H} 1299$ cells, transactivation of p53AIP1 promoter was markedly enhanced four- to fivefold compared with those transfected with p53 alone (Fig. 5A). We next examined whether the effect of $\mathrm{CHC}$ on p53 transactivity is specific for p53AIP1 promoter or general for various p53 target genes, $p 21^{\text {waf } 1}, p 53 R 2$, and Noxa. Figure $5 \mathrm{~A}$ shows that the p53-dependent transactivation of all promoters used was enhanced by the expression of CHC. Among them, CHC is the most effective p53AIP1 promoter, suggesting that $\mathrm{CHC}$ may contribute in part to promoter selectivity. AML1 (Runxl/CBFA1) is a transcription factor essential for hematopoiesis and functions cooperatively with coactivators including p300/ $\mathrm{CBP}$ to activate various target genes, including granzyme $\mathrm{B}$ (CCP1). To examine whether the enhancement of transcription by $\mathrm{CHC}$ is specific for p53, we performed a reporter assay using a promoter of $C C P 1$, which is activated in response to AML1 expression, AML1-responsive promoter (non-p53-responsive promoter) (Wargnier et al. 1995; Kitabayashi et al. 1998, 2001). CHC did not affect the transactivation of AML1-dependent promoter (Fig. $5 \mathrm{~A})$. To further confirm the effect of $\mathrm{CHC}$ on a promoter that does not contain the p53-responsive element, we used a promoter of the bcl-2 gene (Bcl-2-P1P2-Luc), which encodes an antiapoptotic protein (Decary et al. 2002). Transactivation from the promoter of the $b c l-2$ gene was also not influenced by the expression of $\mathrm{CHC}$ (Fig. 5A). Thus, CHC did not affect the transactivation of non-p53-responsive promoters, $C C P 1$ and $b c l-2$ (Fig. 5A). These data suggest that $\mathrm{CHC}$ is a specific coregulator for p53-mediated transcription, although we cannot exclude the possibility that $\mathrm{CHC}$ might be involved in other transcriptional regulation, like the family of p300/CBP histone acetyltransferases (Chan and La Thangue 2001).

We then addressed the effect of $\mathrm{CHC}$ on p53-induced apoptosis. H1299 cells transfected with both p53 and 
Enari et al.

A
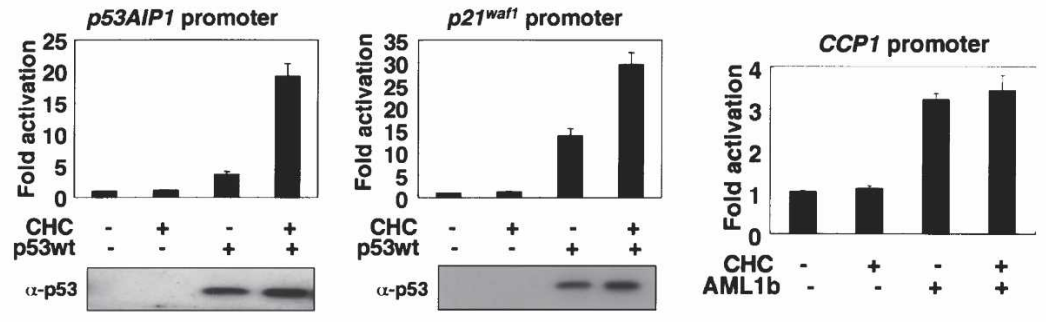

Figure 5. CHC participates in p53-mediated transactivation. (A) $\mathrm{CHC}$ enhances the transactivation of various p53-responsive promoters. H1299 cells were transfected with $1 \mathrm{ng}$ of empty vector, p53 with $400 \mathrm{ng}$ of empty vector, or CHC in combination with $200 \mathrm{ng}$ of the indicated reporter vector, and luciferase activity was measured at $24 \mathrm{~h}$ after transfection. The expression levels of p53 transfected are shown at the bottom. (B) Caspase-3/7 activity in $\mathrm{H} 1299$ cells transfected with indicated plasmids was measured. $(C) \mathrm{CHC}$ induces p53-dependent apoptosis. MCF-7 (top) and H1299 (bottom) cells transfected with control vector (left) or pc-CHC (right) were observed under microscopes. $D$ shows the percentage of dead cells. (E) Partial ablation of CHC by RNAi attenuates p53-mediated transcription. MCF-7 cells were transfected with each RNAi vector, followed by $\gamma$-irradiation at the indicated doses. Whole-cell lysates were analyzed by immunoblotting using the indicated antibodies. TRAP150 and Mre11 were used as loading controls. $(F) \mathrm{CHC}$ binds to the promoters of p53 target genes in vivo. MCF-7 cells were treated with $10 \mathrm{nM}$ Actinomycin $\mathrm{D}$ (Act $\mathrm{D}$ ) for $16 \mathrm{~h}$ and fixed with $1 \%$ formaldehyde, and the cell lysates were immunoprecipitated with the indicated antibodies. DNA fragments eluted from immunoprecipitates were amplified by PCR using specific primers.
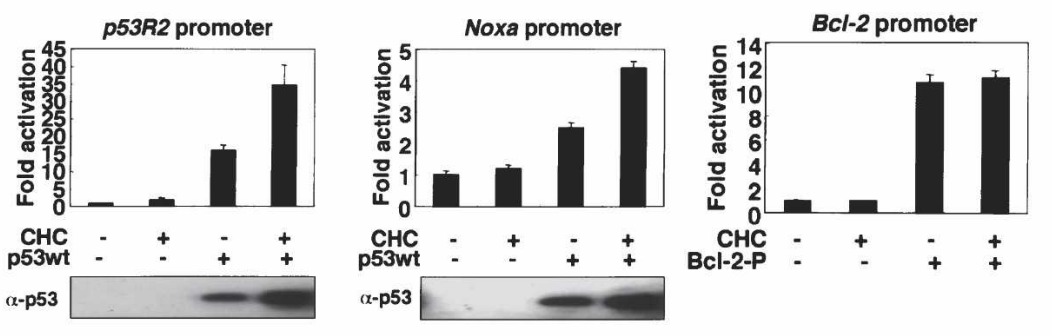

B

C

D
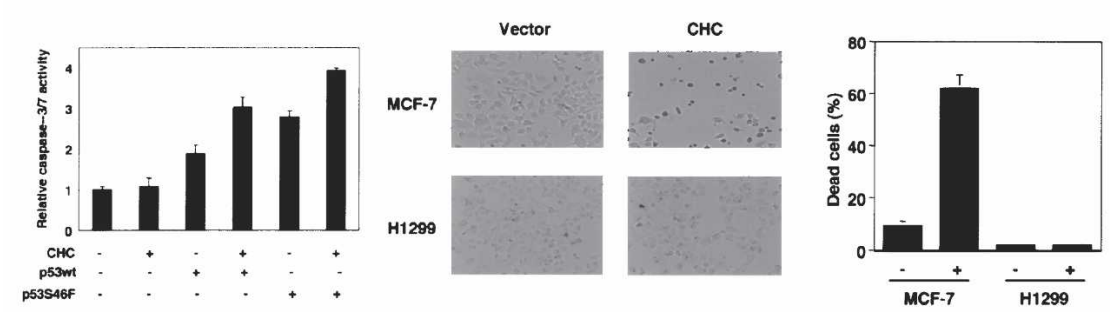

$\mathbf{E}$

$\mathbf{F}$

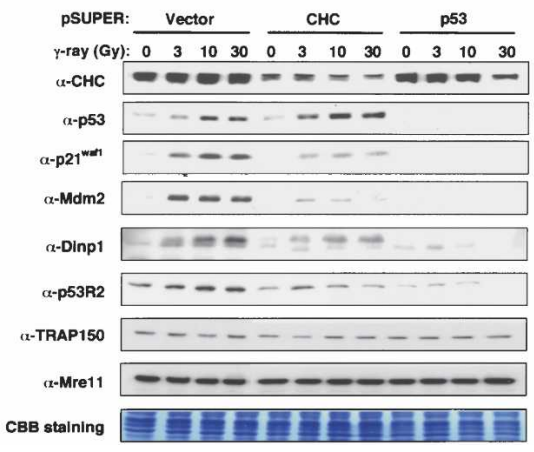

CHC underwent apoptosis more efficiently than those transfected with p53 alone, as judged by caspase activation (Fig. 5B). Moreover, when CHC was overexpressed in MCF-7 cells expressing p53wt, they detached from the dish and underwent apoptosis within $24 \mathrm{~h}$ after transfection, although p53-null cells (H1299) did not (Fig. 5C,D). These data suggest that $\mathrm{CHC}$ is involved in p53-mediated apoptosis.

To assess the involvement of $\mathrm{CHC}$ in p53-mediated transcription, the expression of CHC in MCF-7 cells was knocked down by a vector-based RNA interference (RNAi) technique (Brummelkamp et al. 2002). Reduction of the expression level of endogenous $\mathrm{CHC}$ in MCF-7 cells by small hairpin RNA (shRNA) against $\mathrm{CHC}$ (CHC-1 and $\mathrm{CHC}-2$ ) attenuated the expression of various p53-responsive genes, although p53 was stabilized and accumulated in the cells in response to DNA damage (Fig. 5E; Supplementary Fig. S3). In contrast, control genes, TRAP150, Mre11, and Actin, were not affected (Fig. 5E; Supplementary Fig. S3). RT-PCR analysis revealed that attenuation of the induction of p53 target genes occurred at the RNA transcription level (data not shown). These data suggest that $\mathrm{CHC}$ is indeed required for the transcriptional activation of p53 target genes. We next examined whether the cellular localization of p53 is altered by shRNA against $\mathrm{CHC}$. The reduction of $\mathrm{CHC}$ 
expression by shRNA did not alter the localization of p53, as judged by fluorescence microscopy (Supplementary Fig. S4). Therefore, these results suggest that the loss of CHC expression leads to the reduced p53 transactivation without any alteration of p53 cellular localization.

To confirm whether CHC directly binds to p53-responsive promoter in vivo, we performed a chromatin immunoprecipitation (ChIP) assay. Cells were treated with or without Actinomycin D (ActD), cross-linked, and chromatin was immunoprecipitated with either anti-p53 or anti-CHC antibody, followed by PCR analysis of $p 21^{\text {waf1 }}$ or $p 53 A I P 1$ promoter. The expected DNA fragments containing a p53-binding site were immunoprecipitated not only with anti-p53 antibody, but also with anti-CHC antibody, whereas negative controls of GAPDH and the distal region to p53-binding site in the p2 $1^{\text {waf1 }}$ promoter were not (Fig. 5F). These results strongly support $\mathrm{CHC}^{\prime}$ s function as a coactivator of $\mathrm{p} 53$.

\section{Expression of CLC in nuclei inhibits p53-mediated transcription}

The C-terminal region containing CLC-binding and trimerization domains is required for interaction with p53 (Fig. 4A). To investigate whether CLC inhibits the interaction between $\mathrm{CHC}$ and p53, we performed an in vitro competition assay using two isoforms of CLC, CLCa and $\mathrm{CLCb}$. When recombinant CLCa or CLCb was reacted with CHC prior to incubation with p53-immobilized beads, the association of $\mathrm{CHC}$ with p53 was greatly inhibited (Fig. 6A). CLC has three conserved Trp residues (codons 106, 128, and 139 in human CLCb) that contact with CHC, and it has been reported that the CLC muta-
A

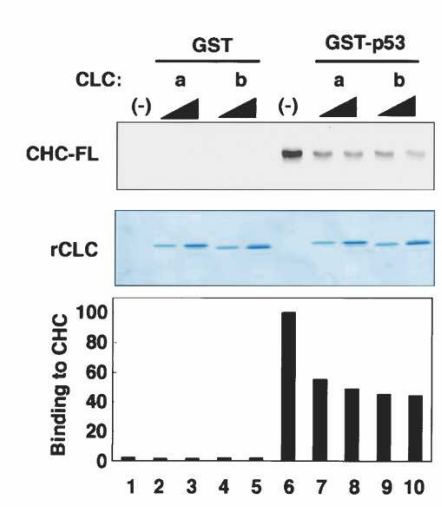

C

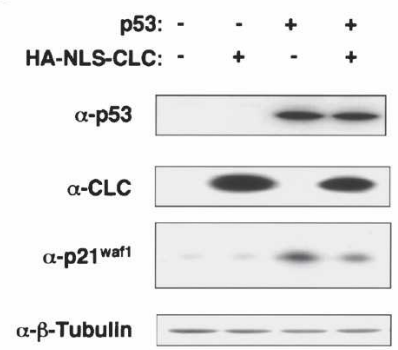

B

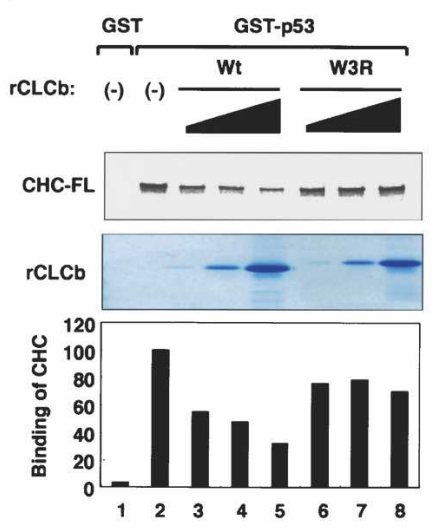

D

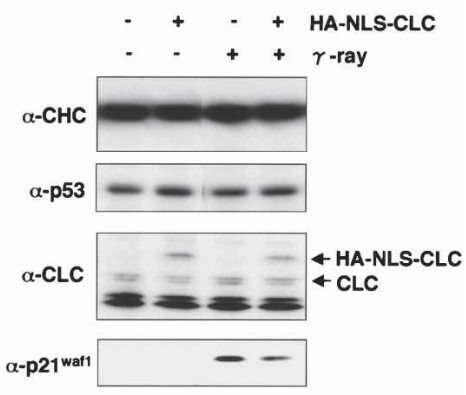

E

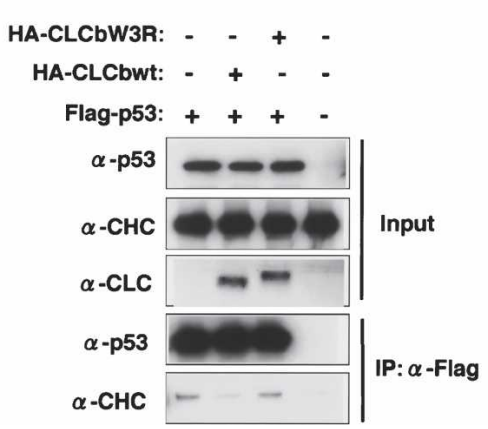

Figure 6. Expression of CLC in nuclei inhibits p53mediated transcription. $(A)$ Inhibition of the interaction of CHC with p53 by recombinant CLC. ${ }^{35}$ S-labeled $\mathrm{CHC}$ synthesized in reticulocyte lysates was incubated with or without (columns 1,5) either recombinant CLCa or CLCb at two concentrations $(1.2 \mu \mathrm{g} / \mathrm{mL}$, columns 2,4,7,9; $4.7 \mu \mathrm{g} / \mathrm{mL}$, columns 3,5,8,10), followed by the reaction with GST beads (columns 1-5) or p53-immobilized beads (columns 6-10). (Top) After extensive washing, the bound ${ }^{35}$ S-labeled CHC was separated by $5 \%-20 \%$ PAGE and visualized by autoradiography. (Middle) Coomassie brilliant blue staining of recombinant CLC proteins is indicated. (Bottom) The intensity of relative $\mathrm{CHC}$ binding to p53 was quantified by PhosphorImager. $(B)$ Dose dependency of CLCb on the inhibition of p53-CHC interaction. ${ }^{35}$ S-labeled CHC was incubated with or without (columns 1,2) either recombinant CLCbwt or CLCbW3R at various concentrations $(0.23 \mu \mathrm{g} / \mathrm{mL}$, columns 3,6; $12 \mu \mathrm{g} / \mathrm{mL}$, columns 4,7; $115 \mu \mathrm{g} / \mathrm{mL}$, columns 5,8) and then reacted with p53immobilized beads. (Top) The bound ${ }^{35}$ S-labeled CHC was detected by autoradiography as above. (Middle) Coomassie brilliant blue staining of CLCb proteins is shown. (Bottom) The intensity of relative $\mathrm{CHC}$ binding to 553 was quantified by PhosphorImager. $(C, D)$ Reduction of $\mathrm{p} 21^{\text {wafl }}$ induction by HA-NLS-CLC. H1299 cells were transfected with p53 in the absence or presence of HA-NLS-CLC $(C)$ or MCF-7 cells transfected with HA-NLS-CLC were irradiated by $\gamma$-ray at $10 \mathrm{~Gy}(D)$, and the protein level of $\mathrm{p} 21^{\text {wafl }}$ in the cell lysates was assayed by immunoblotting with the indicated antibodies. (E) Inhibition of the association of p53 with $\mathrm{CHC}$ by $\mathrm{CLCb}$ in $\mathrm{H} 1299$ cells through direct binding of $\mathrm{CLCb}$ to $\mathrm{CHC}$. Flag-p53 plasmid was transfected with or without either HA-NLS-CLCbwt or HA-NLSCLCbW3R in H1299 cells, and the cells were harvested at $24 \mathrm{~h}$ after transfection. Flag-p53 in the cell lysates was immunoprecipitated with anti-Flag antibody, followed by immunoblotting with anti-p53 and anti-CHC antibodies. 
tions at these Trp residues to Arg lead to the loss of function for CHC binding (Chen et al. 2002). We engineered a CLCb mutant with triple substitutions of Trp to Arg residues (CLCbW3R) and performed an in vitro competition assay to show whether the CHC binding of CLC is needed for the prevention of p53-CHC interaction. In a control experiment, we confirmed that CLCbW3R did not bind to CHC in H1299 cells (Supplementary Fig. S5). Wild-type CLCb (CLCbwt) inhibited p53-CHC interaction in a dose-dependent manner, whereas CLCbW3R had no effect, even when a large amount of CLCbW3R protein was added, indicating that CLCb dissociates the interaction of $\mathrm{CHC}$ with p53 by direct binding of CLC to CHC (Fig. 6B). These results suggest that the association of p53 with $\mathrm{CHC}$ is exclusive to $\mathrm{CHC}-\mathrm{CLC}$ interaction, consistent with the fact that CLC is absent from nuclear CHC-p53 complex.

These results prompted us to examine whether CLC could block p53-mediated transcription. CLC was fused with the nuclear localization signal (NLS) of the SV40 T antigen at the $\mathrm{N}$ terminus to localize at the nucleus and not to affect endocytic function. The expression of NLSCLC inhibited the induction of endogenous $\mathrm{p} 21^{\text {waf } 1}$ by the ectopic expression of p53 in p53-null cells (Fig. 6C) and by $\gamma$-irradiation to p53-positive cells (Fig. 6D). Moreover, knocking down the CLC expression by RNAi stabilized p53 protein and enhanced p53-mediated p21 waf1 induction by $\gamma$-irradiation (data not shown). These data strongly support that p53-CHC interaction is crucial for sufficient transcription mediated by $\mathrm{p} 53$. To assess whether CLC inhibits p53-CHC interaction in vivo, Flag-tagged p53 was transfected with or without either CLCwt or CLCW3R in H1299 cells. When Flag-p53 was pulled down with the anti-Flag antibody, endogenous CHC was coprecipitated in the absence of CLCbwt. In contrast, in cells transfected with CLCbwt but not CLCW3R, the amount of CHC precipitating with p53 dramatically decreased, indicating that CLC directly blocks p53 CHC association by binding to $\mathrm{CHC}$ (Fig. $6 \mathrm{E})$.

\section{CHC stabilizes p300-p53 interaction}

It has been shown that p300 bearing histone acetyltransferase activity participates in p53-mediated transcription (Gu and Roeder 1997; Lill et al. 1997). To investigate the mechanism by which CHC cooperates with p53 to stimulate its transcriptional activity, we tested the effect of $\mathrm{CHC}$ on the interaction of p53 with p300. The binding of p300 to p53 obviously increased in a CHC dose-dependent manner (Fig. 7A) and p53 acetylation at Lys382 increased by CHC expression (Fig. 7B). In addition, CHC formed a complex with p53 and p300 in response to DNA damage (Fig. 7C). These results suggest that $\mathrm{CHC}$ is involved in the regulation of p53-mediated transcription in cooperation with p300. To assess the effect of $\mathrm{CHC}$ on the p300-mediated activation of p53 target genes, we performed a reporter assay using $p 53$ AIP 1 promoter. When p300 was transfected with p53 in H1299 cells, the transactivation of p53AIP1 promoter was slightly enhanced compared with those transfected with p53 alone (Fig. 7D). In contrast, when p300 was transfected with p53 together with $\mathrm{CHC}$, transactivation was greatly increased four- to fivefold compared with those transfected with p53 alone (Fig. 7D). The p300 fragment (residues 1514-1922) containing the p53-binding domain inhibits the activation of p53-mediated transcription and acts as a dominant-negative mutant (Avantaggiati et al. 1997). Therefore, we examined the effect of the dominant-negative p300 fragment (p300DN-Flag) on the CHC-mediated transactivation of $\mathrm{p} 53$. The expression of p300DN-Flag in H1299 cells prevented the CHC-mediated transactivation of $\mathrm{p} 53$, indicating that $\mathrm{CHC}$ mediates p300 (Fig. 7E). Furthermore, reduction of the expression level of cellular CHC by RNAi markedly decreased the targeting of p53 and p300 to p21 promoter in vivo (Fig. 7F). These data suggest that CHC plays a role in the sufficient recruitment of p300 and p53 to p53-responsive promoters and might function as a scaffold protein bridging p53 and p300.

\section{Discussion}

Although many factors are thought to contribute to p53mediated transcription, the detailed mechanisms are poorly understood because of the dynamic processes in p53-transcriptional regulation. Here, we found a p53 mutant (p53S46F) that enhances its transcriptional activity, and this mutation lead to the stabilization of the association with a protein of $190 \mathrm{kDa}$. Surprisingly, mass spectrometric analysis and immunoblotting revealed that this protein was a large subunit of clathrin $\mathrm{CHC}$ known as a main component of endocytosis (Fig. 2). Clathrin has been studied for decades and its role has been restricted to a cytoplasmic function in endocytosis and protein sorting (Conner and Schmid 2003). However, we found that a small fraction of $\mathrm{CHC}$ is present in the nucleus and that nuclear CHC promotes p53-mediated transcription in collaboration with p300 (Fig. 7G). Moreover, we demonstrated that p53-transcriptional activation occurs via the interaction between the $\mathrm{N}$-terminal transactivation domain of p53 and C-terminal domain of $\mathrm{CHC}$ (Fig. 4). As there is a positive correlation between p53-transcriptional activation and the interaction of p53 with CHC after DNA damage (Fig. 2C), it is suggested that $\mathrm{CHC}$ plays an important role in p53-dependent transactivation in vivo and that the post-translational modification of p53 and/or CHC may facilitate this interaction. However, immunoprecipitation analysis showed that a point mutation of p53 at Ser46 to alanine had no or little effect on the binding to $\mathrm{CHC}$ (data not shown), suggesting that another modification at the $\mathrm{N}$ terminus of p53 also appears to contribute to the association with CHC. As p53 bearing a Ser-to-Ala mutation at codon 46 (p53S46A) still has the ability to activate downstream p53 target genes such as p $21^{\text {waf } 1}$, Noxa, and p53R2 (K. Oda et al. 2000), it may be difficult to see the alteration of the binding affinity to $\mathrm{CHC}$. Unlike p53S46A, Ser-to-Phe substitution is likely to work as a gain-of-function mutation by being stabilized in the in- 
A

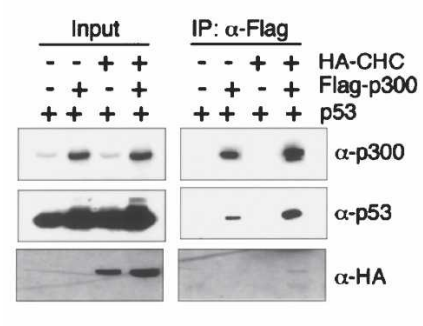

C

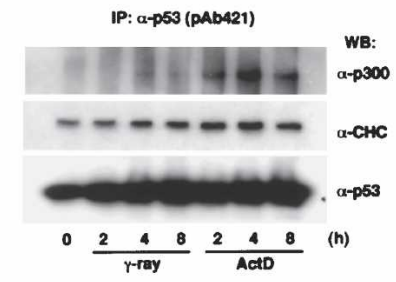

F

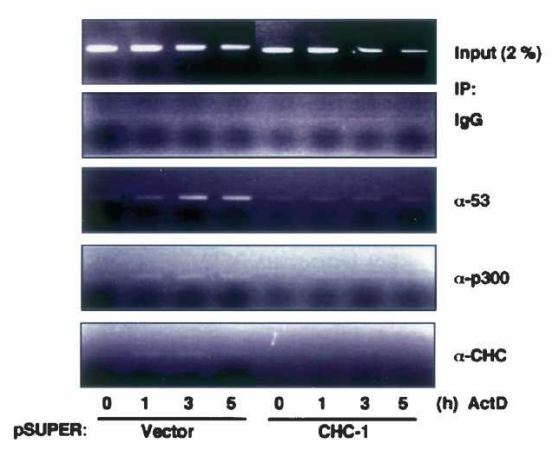

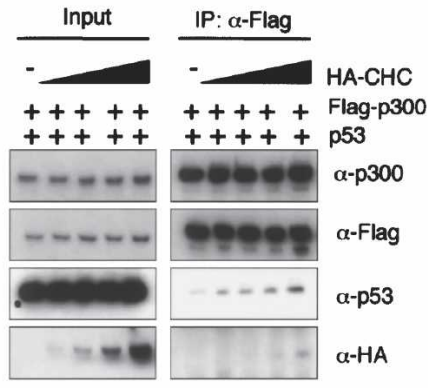

D

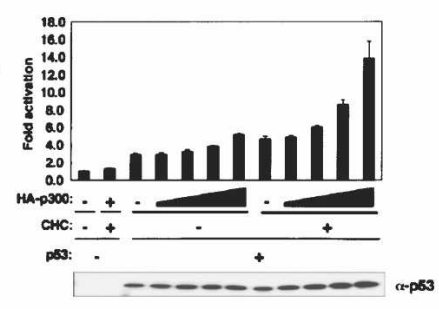

B

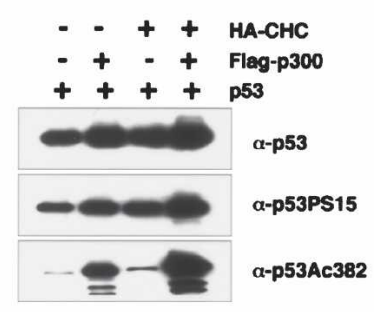

E

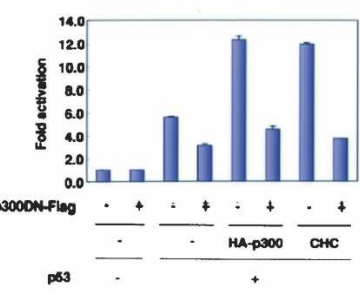

G

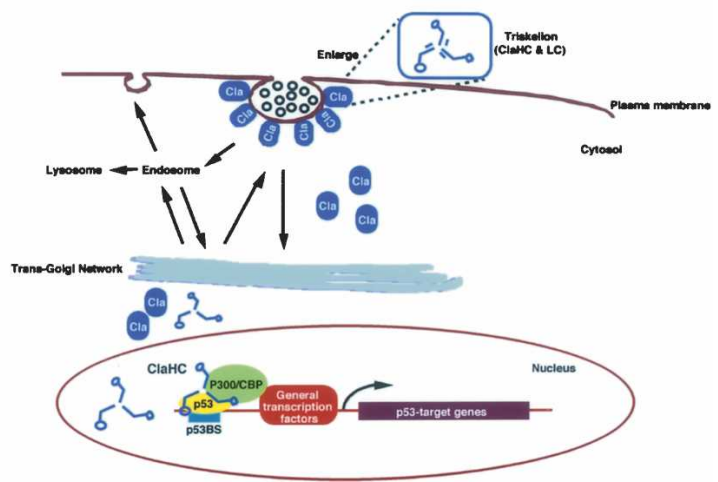

Figure 7. CHC is required for p53-p300 interaction to promote p53-mediated transcription. $(A)$ Increased binding activity of p300 to p53 by CHC. H1299 cells were transfected with the indicated plasmids and incubated for $24 \mathrm{~h}$, and the cell lysates were immunoprecipitated with anti-Flag antibody. The immune complex was resolved by $7.5 \%$ SDS-PAGE, followed by immunoblotting with the indicated antibody. The amounts of plasmid encoding HA-CHC used for the experiment of dose dependency (right) were 0, 1, 2, 4, 8 $\mu \mathrm{g}$, respectively. (B) Increased acetylation of p53 at Lys382 by CHC. Immunoprecipitates in $A$ were immunoblotted with antiacetylated p53 (Lys382) antibody. (C) Complex formation of p53/CHC/p300 by DNA damage. U2-OS cells were irradiated with $\gamma$-ray at 10 Gy or treated with $10 \mathrm{nM}$ ActD for the indicated periods, and the cell lysates were immunoprecipitated with anti-p53 antibody. The immunoprecipitates were immunoblotted with the indicated antibodies. $(D)$ Synergistic effect of p300 and CHC on the transactivation of p53AIP1 promoter. H1299 cells were transfected with $1 \mathrm{ng}$ of empty vector or p53, $200 \mathrm{ng}$ of empty vector or CHC, and 200 ng of empty vector or HA-p300 in combination with $150 \mathrm{ng}$ of the indicated reporter vector, and luciferase activity was measured at $24 \mathrm{~h}$ after transfection. (Bottom) The expression levels of transfected p53 are shown. $(E)$ Inhibition of CHC-mediated p53 transactivation by the expression of the dominant-negative p300 fragment (residues 1514-1922). H1299 cells were transfected with 1 ng of empty vector or p53, $200 \mathrm{ng}$ of empty vector, CHC or HA-p300, and $200 \mathrm{ng}$ of empty vector or p300DN-Flag plus $150 \mathrm{ng}$ of p53AIP1 promoter reporter vector, and luciferase activity was measured at $24 \mathrm{~h}$ after transfection. $(F)$ The targeting of p300 to p21 promoter in vivo. U2-OS cells were transfected with the indicated plasmids, incubated for $72 \mathrm{~h}$, and then treated with $10 \mathrm{nM}$ ActD for the indicated periods. Using these cells, ChIP assay was carried out as described in the Materials and Methods. (G) The role of CHC in p53-mediated transcription. Clathrin triskelions are composed of three $\mathrm{CHC}$ and three associated light chains and function to take up essential nutrients and down-regulate receptor-mediated signaling. However, a small fraction of $\mathrm{CHC}$ is present in the nucleus and is required for p53-mediated transcription following DNA damage.

teraction with $\mathrm{CHC}$ and may enhance transcriptional activity by stabilizing the complex with CHC rather than by mimicking the Ser46 phosphorylation state of p53. It remains unclear why CHC binds p53S46F better than wild-type p53 and why CHC binding to p53 can stabilize the p53-p300 complex. We recently noticed a considerable similarity of the $\mathrm{N}$ terminus of p53 around Ser46 with the CHC-binding region of CLC and an im- 
portant Trp (codon 108 in bovine CLCa) residue for CHC binding is conserved in p53 (Supplementary Fig. S7; Chen et al. 2002); CLC may compete with p53 through this homologous region. We are now investigating whether the conserved residue of p53 is actually required for $\mathrm{CHC}$ binding and we are trying to determine the tertiary structure of the p53-CHC-p300 complex using Xray crystallography. The mechanism will be clarified if the tertiary structure of p53-CHC-p300 complex is determined.

$\mathrm{CHC}$ is likely to be specific for p53 transactivation as evidenced by the fact that $\mathrm{CHC}$ had little or no effect on non-p53-responsive promoters (Fig. 5A), but we cannot rule out the possibility that $\mathrm{CHC}$ may activate other transcriptional machinery, because p300 that can bind $\mathrm{CHC}$ is required for the transactivation of other transcription factors such as E2F-1, Myb, and hypoxia-inducible factor- $1 \alpha$, as well as p53 (Chan and La Thangue 2001).

There have been several lines of evidence showing that cytosolic structural proteins such as $\beta$-actin and spectrin play important roles in nuclear processes ranging from chromatin remodeling to transcription (Rando et al. 2000; Olave et al. 2002). In addition, it has been recently reported that Caveolin-1, a caveolea protein required for caveolin-mediated endocytosis, exists in the nucleus and binds to nuclear lysophosphatidic acid receptor type-1 to modulate the transcription of proinflammatory gene expression (Gobeil et al. 2003). As there has been no report regarding nuclear $\mathrm{CHC}$ localization in the sense that it is changed by external stimuli, it would be interesting to examine whether the localization of $\mathrm{CHC}$ changes in response to certain stimuli, although the alteration of $\mathrm{CHC}$ localization may not be required for the regulation of p53-mediated transcription. In preliminary experiments, we tested the effect of various stimuli including $\gamma$-irradiation, UV, and Adriamycin on CHC localization, but no change in the cellular localization of $\mathrm{CHC}$ was detected (Supplementary Fig. S6; data not shown).

Thus, once p53 accumulates and becomes an active form in response to genotoxic stresses, activated p53 binds nuclear $\mathrm{CHC}$ for the sufficient recruitment of p300 to promote its transcription. It has been recently shown that $\mathrm{p} 300 / \mathrm{CBP}$ associates with various transcriptional regulators through the LXXLL motif (where $\mathrm{L}$ is leucine and $X$ is any amino acid) (Heery et al. 1997; Plevin et al. 2005) and CHC has four LXXLL sequences in the C terminus that are required for the transactivation of p53. However, coimmunoprecipitation analysis using $\mathrm{CHC}$ mutants bearing mutations of LXXLL revealed that all LXXLL sequences were not necessary for both the association with p300 and the increased stability of the p53p300 complex (M. Enari and Y. Taya, unpubl.). Therefore, other regions of $\mathrm{CHC}$ would contribute to the association with p300 and stability of the p53-p300 complex. If drugs enhancing the binding affinity between p53, p300, and CHC are created, they may work as anticancer drugs.

It has been recently shown that clathrin has a second alternative function in mitosis (Royle et al. 2005). Here, we have proposed a third function of clathrin, which is required for p53-mediated transcription. In various tumors, gene fusions of $\mathrm{CHC}$ with anaplastic lymphoma kinase (ALK) and the fusion of $\mathrm{CHC}$ with transcription factor TFE3 have been found and occurred at the $\mathrm{C}$ terminus of CHC (Bridge et al. 2001; Argani et al. 2003; Chikatsu et al. 2003). As our results exhibited that the binding of $\mathrm{p} 53$ to $\mathrm{CHC}$ occurs at the $\mathrm{C}$ terminus of $\mathrm{CHC}$, these fusion proteins might impair the function of p53mediated transcription.

Although the link of p53 to other functions of $\mathrm{CHC}$ including endocytosis and mitosis remains unclear, the discovery of a novel $\mathrm{CHC}$ function, that $\mathrm{CHC}$ enhances p53 activity in tumor cells, could provide new insights into complex p53 transcriptional regulation and useful information for cancer therapy.

\section{Materials and methods}

\section{Immunopurification}

H1299 cells $\left(2 \times 10^{8}\right)$ were harvested at $21 \mathrm{~h}$ after the transfection of Flag-tagged p53 constructs and nuclear extracts were prepared essentially as described (Dignam et al. 1983). Nuclear extracts were diluted fivefold with binding buffer $150 \mathrm{mM}$ Tris at pH 7.2, $150 \mathrm{mM} \mathrm{NaCl}, 2 \mathrm{mM} \mathrm{MgCl} 2,0.1 \mathrm{mM}$ EDTA, $0.1 \mathrm{mM}$ EGTA, $0.5 \mathrm{mM}$ DTT, $1 \mathrm{mM} \mathrm{Na} \mathrm{VO}_{4}, 10 \mathrm{mM} \mathrm{NaF}, 10 \mu \mathrm{g} / \mathrm{mL}$ antipain, $10 \mu \mathrm{g} / \mathrm{mL}$ pepstatin, $10 \mu \mathrm{g} / \mathrm{mL}$ chymostatin, $10 \mu \mathrm{g} / \mathrm{mL}$ leupeptin, $10 \mu \mathrm{g} / \mathrm{mL}$ E-64, $10 \mu \mathrm{g} / \mathrm{mL}$ PMSF, $0.1 \% \mathrm{NP}-40)$ and Flag-tagged proteins were immunoprecipitated with $0.2 \mathrm{~mL}$ $(50 \% \mathrm{v} / \mathrm{v})$ of anti-Flag antibody (M2)-conjugated beads (SigmaAldrich). Flag-tagged proteins were eluted from the beads with $1.5 \mathrm{mg} / \mathrm{mL}$ of Flag peptide in binding buffer at $4^{\circ} \mathrm{C}$ for $2 \mathrm{~h}$ The eluates were resolved by $7.5 \%$ or $5 \%-20 \%$ SDS-PAGE (Biocraft) and proteins were visualized by silver staining or Coomassie blue staining. An associated protein ( $\mathrm{Mr} \sim 190,000)$ was identified by mass spectrometry as previously described (Kitabayashi et al. 2001).

\section{Expression vectors and antibodies}

cDNAs encoding full-length human p53 and its various derivatives, full-length CHC (KIAA0034) and its various derivatives, and p300DN-Flag were subcloned into pcDNA3.1 (Invitrogen), pGEX-4T-1 or pGEX-6P-1 (Amersham Biosciences). DNA fragments encoding all deletion mutants with or without epitope tag were amplified by PCR. cDNAs encoding full-length human CLCa and CLCb were amplified by PCR using cDNA pools from MCF-7 cells and subcloned into pcDNA3.1 so that CLC proteins could be expressed in mammalian cell lines as native forms or fusion types with a haemagglutinin (HA) epitope and nuclear localization signal of SV40 large T antigen. Anti-p53 (DO-1), anti-p53 (pAb421), anti-mdm2 (IF-2), anti-CHC (X.22), and anti-p300 (Ab-1) antibodies were purchased from Oncogene Science; anti-CHC (clone 23) and anti-p2 $1^{\text {wafl }}$ (SX118) antibodies from BD Biosciences; anti-CLC (CON.1), anti-p300 (N-15), anti-TRAP150 (C-18), anti-GST (B-14) antibodies, and anti-p53 antibody (DO-1)-conjugated horseradish peroxidase (HRP) from Santa Cruz Biotechnology; anti-p53R2 and anti-p53Dinp1 antibodies from Abcam, anti-Mre11 antibody from Novus Biochemicals; anti-Flag (M2) antibody from Sigma-Aldrich, HRPconjugated secondary antibodies from Amersham Biosciences; anti-HA (HA.11) antibody from Covance research; and antip300 (RW128) antibody from Upstate Biotechnology. 


\section{Reporter assay}

Saos- 2 cells $\left(4 \times 10^{4}\right)$ or H1299 cells $\left(3 \times 10^{4}\right)$ were seeded in a 24 -well plate and cotransfected with expression vectors in combination with reporter constructs of intron 1-wt for p53AIP1 promoter (K. Oda et al. 2000), WWP-Luc for $p 21^{\text {waf1 }}$ promoter (el-Deiry et al. 1993), 550RE-Luc for p53R2 promoter (Tanaka et al. 2000), Noxa-Luc (E. Oda et al. 2000), CCP1-Luc for granzyme B promoter (Kitabayashi et al. 1998), and Bcl-2-P1P2-Luc (Decary et al. 2002) using Lipofectamine 2000 (Invitrogen). The amount of plasmid DNA used in each experiment is indicated in the figure legends. Carrier DNA was added so that the amount of plasmid DNA remained constant. A phRG-TK plasmid encoding Renilla luciferase (Promega) was mixed in a DNA-liposome complex as an internal control. Luciferase activity was quantified by a dual-luciferase assay system (Promega) and relative transactivation was calculated according to the manufacturer's instructions.

\section{RT-PCR analysis}

Total RNA from H1299 cells transfected with p53-expressing plasmids or shRNA-expressing MCF-7 cells treated with $\gamma$-irradiation at the indicated doses was isolated with RNeasy Mini kit (QIAGEN). Three micrograms of total RNA were reversetranscribed with SuperScript II First-Strand Synthesis System for RT-PCR kit (Invitrogen). One-tenth of the reverse-transcribed materials was used in the PCR reactions. PCR programs and primers used for PCR were as follows: a $94^{\circ} \mathrm{C}, 2$-min initial denaturation step, 33 cycles (for p53AIP1, 5'-GGCCCTAACA CAAATGAGG- $3^{\prime}$ and $5^{\prime}$-ACGAAGATCCAGACGAGACT- ${ }^{\prime}{ }^{\prime}$, 32 cycles (for $\mathrm{p} 21^{\text {wafl }}, 5^{\prime}$-AGTGGACAGCGAGCAGCTGAGC$3^{\prime}$ and 5'-GCAGCAGCGCAGGTGACGGC-3'), 23 cycles (for PIG3, 5'-GCAGCTGCTGGATTCAATTAC-3' and 5'-GCCT ATGTTCTTGTTGGCCTC-3'), 29 cycles (for PUMA, 5'-TGT GAATCCTGTGCTCTGCC-3' and 5'-TTCCGGTATCTACA GCAGCG-3'), and 23 cycles (for GAPDH, 5'-TCCACAGTC TTCTGGGTGGCAGTGA-3' and 5'-GGGGAGCCAAAAGGG TCATCATCTC- $\left.3^{\prime}\right)$ at $94^{\circ} \mathrm{C}$ for $30 \mathrm{sec}, 55-60^{\circ} \mathrm{C}$ for $30 \mathrm{sec}$, and $72^{\circ} \mathrm{C}$ for $1 \mathrm{~min}$ on a PTC-200 DNA Engine thermal cycler (MJ Research, Inc.). PCR amplification was performed in the linear range and PCR products were solved by $2 \%$ agarose gel electrophoresis. The amplified DNA fragments were quantified by NIH Image version 1.61 densitometry.

\section{Assay for apoptotic activity}

For caspase assay, H1299 cells $\left(2 \times 10^{5}\right)$ were transfected with the indicated amounts of pC53-SN3 and/or pc-CHC expression vectors and harvested at $16 \mathrm{~h}$ after transfection. Caspase activity was quantified by CaspACE Assay System (Promega) and specific activity was calculated according to the instructions.

\section{RNAi experiment}

For the expression of short-hairpin RNA, oligonucleotides containing homologous sequences to $\mathrm{CHC}$ (CHC-1, 5'-GATCCCC GTAATCCAATTCGAAGACCTTCAAGAGAGGTCTTCGA ATTGGATTACTTTTTGGAAA-3' and 5' -AGCTTTTCCAAA AAGTAATCCAATTCGAAGACCTCTCTTGAAGGTCTTCG AAATTGGATTACGGG-3'); CHC-2, 5'-GATCCCCAGAGCA CCATGATTCCAATTTCAAGAGAATTGGAATCATGGTGC TCTTTTTTGGAAA- $3^{\prime}$ and $5^{\prime}$-AGCTTTTCCAAAAAAGAGC ACCATGATTCCAATTCTCTTGAAATTGGAATCATGGTG CTCTGGG-3') were synthesized and duplex oligo DNA was inserted into the pSUPER vector (a gift from Dr. R. Bernards,
The Netherlands Cancer Institute, Amsterdam, The Netherlands). Synthetic duplex RNAs (5'-GTAATCCAATTCGAAG ACCdTdT-3' and 5'-GGTCTTCGAATTGGATTACdTdT-3') purchased from Qiagen were also used. The plasmid DNA (2$3.5 \mu \mathrm{g})$ was transfected in MCF-7 or U2-OS cells $\left(2 \times 10^{6}\right)$ with Nucleofector apparatus (Amaxa). Transfection efficiency is $\sim 90 \%$ when using a Nucleofector V kit with program Q-28 for MCF-7 cells or with program I-13 for U2-OS cells. At $72 \mathrm{~h}$ after transfection, MCF-7 cells $\left(3 \times 10^{5}\right)$ were exposed to $\gamma$-ray at various doses and incubated for $4 \mathrm{~h}$, and the cell lysates were analyzed by immunoblotting using the indicated antibodies.

\section{Coimmunoprecipitation and immunoblotting}

About $3 \times 10^{7}$ cells (MCF-7 or U2-OS cells) were extracted with $1 \mathrm{~mL}$ of binding buffer for $30 \mathrm{~min}$ on ice and lysates were cleared by centrifugation at $15,000 \mathrm{rpm}$ for $15 \mathrm{~min}$. The supernatants were incubated with $2 \mu \mathrm{g}$ of anti-p53 (pAb421) or anti-CHC (X.22) antibody for $2 \mathrm{~h}$ at $4^{\circ} \mathrm{C}$, and the immune complexes were collected by adding $20 \mu \mathrm{L}$ of protein A plus protein G-sepharose beads (1:1 mixture, $50 \% \mathrm{v} / \mathrm{v}$, Amersham Biosciences) and incubating samples for $1 \mathrm{~h}$ at $4^{\circ} \mathrm{C}$, followed by three washes with 1 $\mathrm{mL}$ binding buffer. The bound proteins were eluted with SDS sample buffer and separated by $7.5 \%$ SDS-PAGE, followed by transfer to PVDF membranes (Millipore). The membranes were blocked with $5 \%$ nonfat dry milk in TBST buffer $(20 \mathrm{mM}$ Tris at $\mathrm{pH} 7.6,137 \mathrm{mM} \mathrm{NaCl}$, and $0.1 \%$ Tween 20 ) and incubated with the first antibody overnight at $4^{\circ} \mathrm{C}$. The blots were washed three times with TBST buffer, incubated with the secondary antibody conjugated to horseradish peroxidase, and then washed four times in TBST buffer. The bands of interest were visualized by chemiluminescence (Amersham Biosciences). For analysis of the stabilization of the p53-p300 complex by CHC, H1299 cells $\left(1.4 \times 10^{6}\right)$ were transfected with $0.5 \mu \mathrm{g}$ of empty vector or p53, $8 \mu \mathrm{g}$ of empty vector or Flag-p300, and $8 \mu \mathrm{g}$ of empty vector or HA-CHC using Lipofectamine 2000 and incubated for $24 \mathrm{~h}$. The cell lysates were obtained as described above and incubated with $40 \mu \mathrm{L}$ of $\mathrm{M} 2$-agarose beads $(50 \% \mathrm{v} / \mathrm{v})$ for $2 \mathrm{~h}$ at $4^{\circ} \mathrm{C}$. After extensive washing with binding buffer, the bound proteins were visualized by immunoblotting using the indicated antibodies.

\section{ChIP assay}

ChIP assay was performed using an acetyl-histone H3 ChIP Assay kit (Upstate Biotechnology) as recommended by the manufacturer, except that anti-p53 (DO-1), anti-CHC (X.22), antip300 (1:1 mixture of RW128 and Ab-1) antibodies, and protein A plus protein G-sepharose beads (1:1 mixture) were used instead of anti-histone $\mathrm{H} 3$ antibody and protein $\mathrm{A}$-agarose beads, respectively, and $\mathrm{LiCl}$ washing was omitted. MCF-7 cells $\left(2 \times 10^{6}\right)$ incubated in the absence or presence of $10 \mathrm{nM}$ actinomycin $\mathrm{D}$ for $16 \mathrm{~h}$ or U2-OS cells $\left(1 \times 10^{7}\right)$ treated with $5 \mathrm{nM}$ Actinomycin $\mathrm{D}$ for indicated periods were used for ChIP assay. For PCR amplification, the specific primers, 5'-CCAGCCCTTTGGATGG TTT-3' and 5'-GCCTCCTTTCTGTGCCTGA-3' for p2 $1^{\text {waf } 1}$ promoter; 5'-CCTTCTCCTAGCTCTGTCC-3' and 5' -GACTG GGACAGCTGGAATG-3' for p53AIP1 intron 1 ; 5' 5 $^{\prime}$-AACTC GGCCAGGCTCAGCT-3' and 5'-CTCTCACCTCCTCTGAG TGC-3' for the distal region to the p53-binding site in the p21 $1^{\text {wafl }}$ promoter; and 5'-AAAAGCGGGGAGAAAGTAGG-3' and 5'-CTAGCCTCCCGGGTTTCTCT-3' for GAPDH were used. PCR amplification was performed in the linear range.

\section{In vitro binding assay}

cDNAs encoding full-length p53, its mutant derivatives, and CLC proteins were amplified by PCR, cloned into pGEX-4T-1 or 
pGEX-6P-1 vector (Amersham Biosciences) and expressed in Escherichia coli, and GST fusion proteins were purified as recommended in the instructions (Amersham Biosciences). ${ }^{35} \mathrm{~S}$-labeled wild-type $\mathrm{CHC}$ and its mutants were synthesized using in vitro transcription/translation-coupled reticulocyte lysates (Promega). ${ }^{35}$ S-labeled proteins were pulled down with GST fusion proteins. Samples were subjected to 5\%-20\% SDS-PAGE and analyzed by autoradiography. To obtain recombinant CLC proteins, GST fusion CLC proteins were cleaved by PreScission protease (Amersham Biosciences) on glutathione Sepharose 4B following the manufacturers' protocols. For in vitro competition assay using recombinant $\mathrm{CLC},{ }^{35} \mathrm{~S}$-labeled $\mathrm{CHC}$ was reacted with CLC for $60 \mathrm{~min}$ at $4^{\circ} \mathrm{C}$ prior to incubation with GST-p53, and GSTpull-down assay was carried out as above.

\section{Cell fractionation and immunofluorescence}

Cell fractionation was carried out as described elsewhere (Dignam et al. 1983) with several modifications. In brief, MCF-7 cells $\left(4 \times 10^{6}\right)$ were lysed in $1 \mathrm{~mL}$ of Buffer A (10 mM HEPES at $\mathrm{pH} 7.9,1.5 \mathrm{mM} \mathrm{MgCl}, 10 \mathrm{mM} \mathrm{KCl}, 0.5 \mathrm{mM} \mathrm{DTT}, 1 \mathrm{mM}$ $\mathrm{Na}_{3} \mathrm{VO}_{4}, 10 \mathrm{mM} \mathrm{NaF}, 10 \mu \mathrm{g} / \mathrm{mL}$ antipain, $10 \mu \mathrm{g} / \mathrm{mL}$ pepstatin, $10 \mu \mathrm{g} / \mathrm{mL}$ chymostatin, $10 \mu \mathrm{g} / \mathrm{mL}$ leupeptin, $10 \mu \mathrm{g} / \mathrm{mL}$ E- 64,10 $\mu \mathrm{g} / \mathrm{mL}$ PMSF) containing $0.5 \%$ NP-40 by vortex for $10 \mathrm{sec}$. The homogenates were checked microscopically for cell lysis and centrifuged for $5 \mathrm{~min}$ at $1000 \times \mathrm{g}$ to pellet nuclei. The supernatants were collected and used as cytosolic fractions. Pelleted nuclei were washed twice with Buffer A and used for immunofluorescence analysis. Nuclear fractions were extracted from nuclei with $50 \mu \mathrm{L}$ of Buffer B (25 mM HEPES at pH 7.9, $1.5 \mathrm{mM}$ $\mathrm{MgCl}_{2}, 420 \mathrm{mM} \mathrm{KCl}, 0.5 \mathrm{mM}$ DTT, $10 \%$ glycerol, $1 \mathrm{mM}$ $\mathrm{Na}_{3} \mathrm{VO}_{4}, 10 \mathrm{mM} \mathrm{NaF}, 10 \mu \mathrm{g} / \mathrm{mL}$ antipain, $10 \mu \mathrm{g} / \mathrm{mL}$ pepstatin, $10 \mu \mathrm{g} / \mathrm{mL}$ chymostatin, $10 \mu \mathrm{g} / \mathrm{mL}$ leupeptin, $10 \mu \mathrm{g} / \mathrm{mL}$ E- 64,10 $\mu \mathrm{g} / \mathrm{mL}$ PMSF).

Cytosolic and nuclear fractions from MCF-7 cells were subjected to immunoblotting as above. For immunohistochemical analysis, isolated nuclei were fixed with a FIX and PERM kit (Caltag Laboratories) on a poly-L-lysine-coated slide (IWAKI). The nuclei were blocked in 3\% BSA/phosphate-buffered saline (PBS) for $30 \mathrm{~min}$, incubated with primary antibodies for $1 \mathrm{~h}$, stained with AlexFluor-conjugated secondary antibody (Molecular Probe, Inc.), and mounted with Vectashield reagent (Vector Laboratories). Immunofluorescence was performed using a Nikon ECLIPSE E1000 fluorescence microscope.

\section{Immuno-electron microscopic analysis}

For immuno-electron microscopy, cells were fixed in $4 \%$ paraformaldehyde plus $0.05 \%$ glutaraldehyde at $4^{\circ} \mathrm{C}$ for $1 \mathrm{~h}$. They were sequentially dehydrated with $50 \%$ and $70 \%$ ethanol at $4{ }^{\circ} \mathrm{C}$ for $20 \mathrm{~min}$ and then embedded in LR-White resin at $40^{\circ} \mathrm{C}$ for 4 d. Very thin sections were cut with a cryo-ultramicrotome. The ultrathin cryosections used were $\sim 80 \mathrm{~nm}$ thick and were incubated with blocking buffer ( $1 \%$ BSA in PBS) plus $0.05 \%$ Tween20 at RT for $15 \mathrm{~min}$. After blocking, the sections were incubated with normal mouse IgG (Santa Cruz Biotechnology) or antiCHC antibody (X.22) in blocking buffer at $4^{\circ} \mathrm{C}$ overnight, followed by incubation with anti-mouse IgG $10-\mathrm{nm}$ colloidal gold particles at RT for $1 \mathrm{~h}$. For visualization and preservation of the ultrastructure of cryosections, the sections on grids were postfixed with ferrocyanide-reduced osmium and then stained with uranyl acetate and lead citrate in polyvinyl alcohol.

\section{Acknowledgments}

We thank T. Nagase and M. Ohishi (Kazusa DNA Research Institute) for cDNA encoding full-length $\mathrm{CHC}, \mathrm{R}$. Agami and R.
Bernards (The Netherlands Cancer Institute) for pSUPER and pSUPER-p53 vectors, K. Tamai and S. Fukuzawa (CycLex Corporation) for the construction of various p53 mutants, C.E. Cremisi (Institut Andre Lwoff) for Bcl-2-P1P2 promoter, B. Vogelstein (Johns Hopkins University) for WWP-Luc, H. Arakawa and Y. Nakamura (The University of Tokyo) for Intron 1-wt and 550RE-Luc, T. Shibue and T. Taniguchi (The University of Tokyo) for Noxa-Luc, K. Yamamoto and N. Matsumoto (The University of Tokyo) for useful discussion, and $\mathrm{T}$. Tanaka for help at the initial stage of this work. This work was partly supported by MEXT, KAKENNHI (12219218), the Program for Promotion of Fundamental Studies in Health Sciences of Organization for Pharmaceutical Safety and Research of Japan, a Research Grant from the Princess Takamatsu Cancer Research Fund, a grant from the Tokyo Biochemical Research Foundation, and a grant from Takeda Science Foundation (to Y.T.)

\section{References}

Argani, P., Lui, M.Y., Couturier, J., Bouvier, R., Fournet, J.C., and Ladanyi, M. 2003. A novel CLTC-TFE3 gene fusion in pediatric renal adenocarcinoma with $\mathrm{t}(\mathrm{X} ; 17)(\mathrm{p} 11.2 ; \mathrm{q} 23)$. Oncogene 22: 5374-5378.

Avantaggiati, M.L., Ogryzko, V., Gardner, K., Giordano, A., Levine, A.S., and Kelly, K. 1997. Recruitment of p300/CBP in p53-dependent signal pathways. Cell 89: 1175-1184.

Behrens, J., von Kries, J.P., Kuhl, M., Bruhn, L., Wedlich, D., Grosschedl, R., and Birchmeier, W. 1996. Functional interaction of $\beta$-catenin with the transcription factor LEF-1. $\mathrm{Na}$ ture 382: 638-642.

Bourdon, J.C., Laurenzi, V.D., Melino, G., and Lane, D. 2003. p53: 25 years of research and more questions to answer. Cell Death Differ. 10: 397-399.

Bridge, J.A., Kanamori, M., Ma, Z., Pickering, D., Hill, D.A., Lydiatt, W., Lui, M.Y., Colleoni, G.W., Antonescu, C.R., Ladanyi, M., et al. 2001. Fusion of the ALK gene to the clathrin heavy chain gene, CLTC, in inflammatory myofibroblastic tumor. Am. J. Pathol. 159: 411-415.

Brummelkamp, T.R., Bernards, R., and Agami, R. 2002. A system for stable expression of short interfering RNAs in mammalian cells. Science 296: 550-553.

Chan, H.M. and La Thangue, N.B. 2001. p300/CBP proteins: HATs for transcriptional bridges and scaffolds. J. Cell Sci. 114: 2363-2373.

Chen, X., Ko, L.J., Jayaraman, L., and Prives, C. 1996. p53 levels, functional domains, and DNA damage determine the extent of the apoptotic response of tumor cells. Genes \& Dev. 10: $2438-2451$.

Chen, C.Y., Reese, M.L., Hwang, P.K., Ota, N., Agard, D., and Brodsky, F.M. 2002. Clathrin light and heavy chain interface: $\alpha$-Helix binding superhelix loops via critical tryptophans. EMBO J. 21: 6072-6082.

Chikatsu, N., Kojima, H., Suzukawa, K., Shinagawa, A., Nagasawa, T., Ozawa, H., Yamashita, Y., and Mori, N. 2003. ALK+, CD30-, CD20- large B-cell lymphoma containing anaplastic lymphoma kinase (ALK) fused to clathrin heavy chain gene (CLTC). Mod. Pathol. 16: 828-832.

Conner, S.D. and Schmid, S.L. 2003. Regulated portals of entry into the cell. Nature 422: $37-44$

Decary, S., Decesse, J.T., Ogryzko, V., Reed, J.C., Naguibneva, I., Harel-Bellan, A., and Cremisi, C.E. 2002. The retinoblastoma protein binds the promoter of the survival gene bcl-2 and regulates its transcription in epithelial cells through transcription factor AP-2. Mol. Cell. Biol. 22: 7877-7888.

Dignam, J.D., Lebovitz, R.M., and Roeder, R.G. 1983. Accurate 
transcription initiation by RNA polymerase II in a soluble extract from isolated mammalian nuclei. Nucleic Acids Res. 11: $1475-1489$.

el-Deiry, W.S., Tokino, T., Velculescu, V.E., Levy, D.B., Parsons, R., Trent, J.M., Lin, D., Mercer, W.E., Kinzler, K.W., and Vogelstein, B. 1993. WAF1, a potential mediator of p53 tumor suppression. Cell 75: 817-825.

Gobeil, F.J., Bernier, S.G., Vazquez-Tello, A., Brault, S., Beauchamp, M.H., Quiniou, C., Marrache, A.M., Checchin, D., Sennlaub, F., Hou, X., et al. 2003. Modulation of proinflammatory gene expression by nuclear lysophosphatidic acid receptor type-1. J. Biol. Chem. 278: 38875-38883.

$\mathrm{Gu}$, W. and Roeder, R.G. 1997. Activation of p53 sequencespecific DNA binding by acetylation of the p53 C-terminal domain. Cell 90: 595-606.

Heery, D.M., Kalkhoven, E., Hoare, S., and Parker, M.G. 1997. A signature motif in transcriptional co-activators mediates binding to nuclear receptors. Nature 387: 733-736.

Hollstein, M., Sidransky, D., Vogelstein, B., and Harris, C.C. 1991. p53 mutations in human cancers. Science 253: 49-53.

Honda, R., Tanaka, H., and Yasuda, H. 1997. Oncoprotein MDM2 is a ubiquitin ligase E3 for tumor suppressor p53. FEBS Lett. 420: 25-27.

Kirchhausen, T. 2000. Clathrin. Annu. Rev. Biochem. 69: 699727.

Kitabayashi, I., Yokoyama, A., Shimizu, K., and Ohki, M. 1998. Interaction and functional cooperation of the leukemia-associated factors AML1 and p300 in myeloid cell differentiation. EMBO J. 17: 2994-3004.

Kitabayashi, I., Aikawa, Y., Nguyen, L.A., Yokoyama, A., and Ohki, M. 2001. Activation of AML1-mediated transcription by $\mathrm{MOZ}$ and inhibition by the MOZ-CBP fusion protein. EMBO J. 20: 7184-7196.

Levine, A.J. 1997. p53, the cellular gatekeeper for growth and division. Cell 88: 323-331.

Lill, N.L., Grossman, S.R., Ginsberg, D., DeCaprio, J., and Livingston, D.M. 1997. Binding and modulation of p53 by p300/ CBP coactivators. Nature 387: 823-827.

Linke, S.P., Sengupta, S., Khabie, N., Jeffries, B.A., Buchhop, S., Miska, S., Henning, W., Pedeux, R., Wang, X.W., Hofseth, L.J., et al. 2003. p53 interacts with hRAD51 and hRAD54, and directly modulates homologous recombination. Cancer Res. 63: 2596-2605.

Liu, S.H., Wong, M.L., Craik, C.S., and Brodsky, F.M. 1995. Regulation of clathrin assembly and trimerization defined using recombinant triskelion hubs. Cell 83: 257-267.

Ljungman, M. 2000. Dial 9-1-1 for p53: Mechanisms of p53 activation by cellular stress. Neoplasia 2: 208-225.

Marin, M.C., Jost, C.A., Brooks, L.A., Irwin, M.S., O'Nions, J., Tidy, J.A., James, N., McGregor, J.M., Harwood, C.A., Yulug, I.G., et al. 2000. A common polymorphism acts as an intragenic modifier of mutant p53 behaviour. Nat. Genet. 25: 47-54.

Mihara, M., Erster, S., Zaika, A., Petrenko, O., Chittenden, T., Pancoska, P., and Moll, U.M. 2003. p53 has a direct apoptogenic role at the mitochondria. Mol. Cell 11: 577-590.

Oda, E., Ohki, R., Murasawa, H., Nemoto, J., Shibue, T., Yamashita, T., Tokino, T., Taniguchi, T., and Tanaka, N. 2000. Noxa, a BH3-only member of the Bcl-2 family and candidate mediator of p53-induced apoptosis. Science 288: 1053-1058.

Oda, K., Arakawa, H., Tanaka, T., Matsuda, K., Tanikawa, C., Mori, T., Nishimori, H., Tamai, K., Tokino, T., Nakamura, Y., et al. 2000. p53AIP1, a potential mediator of p53-dependent apoptosis, and its regulation by Ser-46-phosphorylated p53. Cell 102: 849-862.

Olave, I.A., Reck-Peterson, S.L., and Crabtree, G.R. 2002.
Nuclear actin and actin-related proteins in chromatin remodeling. Annu. Rev. Biochem. 71: 755-781.

Oren, M. 2003. Decision making by p53: Life, death and cancer. Cell Death Differ. 10: 431-442.

Plevin, M.J., Mills, M.M., and Ikura, M. 2005. The LxxLL motif: A multifunctional binding sequence in transcriptional regulation. Trends Biochem. Sci. 30: 66-69.

Prives, C. and Hall, P.A. 1999. The p53 pathway. J. Pathol. 187: 112-126.

Rando, O.J., Zhao, K., and Crabtree, G.R. 2000. Searching for a function for nuclear actin. Trends Cell Biol. 10: 92-97.

Royle, S.J., Bright, N.A., and Lagnado, L. 2005. Clathrin is required for the function of the mitotic spindle. Nature 434: $1152-1157$.

Samuels-Lev, Y., O'Connor, D.J., Bergamaschi, D., Trigiante, G., Hsieh, J.K., Zhong, S., Campargue, I., Naumovski, L., Crook, T., and Lu, X. 2001. ASPP proteins specifically stimulate the apoptotic function of p53. Mol. Cell 8: 781-794.

Seo, Y.R., Fishel, M.L., Amundson, S., Kelley, M.R., and Smith, M.L. 2002. Implication of p53 in base excision DNA repair: In vivo evidence. Oncogene 21: 731-737.

Shieh, S.Y., Ikeda, M., Taya, Y., and Prives, C. 1997. DNA damage-induced phosphorylation of p53 alleviates inhibition by MDM2. Cell 91: 325-334.

Shieh, S.Y., Taya, Y., and Prives, C. 1999. DNA damage-inducible phosphorylation of p53 at N-terminal sites including a novel site, Ser20, requires tetramerization. EMBO J. 18: 1815-1823.

Siliciano, J.D., Canman, C.E., Taya, Y., Sakaguchi, K., Appella, E., and Kastan, M.B. 1997. DNA damage induces phosphorylation of the amino terminus of p53. Genes \& Dev. 11:34713481.

Tanaka, H., Arakawa, H., Yamaguchi, T., Shiraishi, K., Fukuda, S., Matsui, K., Takei, Y., and Nakamura, Y. 2000. A ribonucleotide reductase gene involved in a p53-dependent cellcycle checkpoint for DNA damage. Nature 404: 42-49.

Tarapore, P. and Fukasawa, K. 2002. Loss of p53 and centrosome hyperamplification. Oncogene 21: 6234-6240.

Taylor, J.A., Li, Y., He, M., Mason, T., Mettlin, C., Vogler, W.J., Maygarden, S., and Liu, E. 1996. p53 mutations in bladder tumors from arylamine-exposed workers. Cancer Res. 56: 294-298.

Vogelstein, B., Lane, D., and Levine, A.J. 2000. Surfing the p53 network. Nature 408: 307-310.

Vousden, K.H. and Lu, X. 2002. Live or let die: The cell's response to p53. Nat. Rev. Cancer 2: 594-604.

Wargnier, A., Legros-Maida, S., Bosselut, R., Bourge, J.F., Lafaurie, C., Ghysdael, C.J., Sasportes, M., and Paul, P. 1995. Identification of human granzyme B promoter regulatory elements interacting with activated T-cell-specific proteins: Implication of Ikaros and CBF binding sites in promoter activation. Proc. Nat1. Acad. Sci. 92: 6930-6934.

Zhu, J., Zhou, W., Jiang, J., and Chen, X. 1998. Identification of a novel p53 functional domain that is necessary for mediating apoptosis. J. Biol. Chem. 273: 13030-13036.

Zhu, J., Jiang, J., Zhou, W., Zhu, K., and Chen, X. 1999. Differential regulation of cellular target genes by p53 devoid of the PXXP motifs with impaired apoptotic activity. Oncogene 18: 2149-2155. 


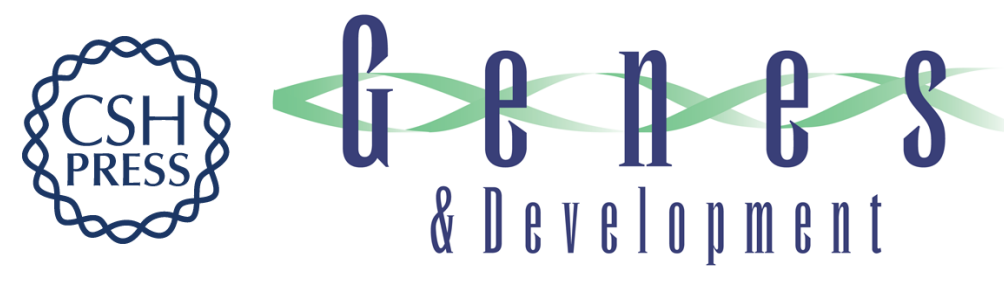

\section{Requirement of clathrin heavy chain for p53-mediated transcription}

Masato Enari, Kazuji Ohmori, Issay Kitabayashi, et al.

Genes Dev. 2006, 20:

Access the most recent version at doi:10.1101/gad.1381906

Supplemental

Material

References

This article cites 50 articles, 15 of which can be accessed free at:

http://genesdev.cshlp.org/content/20/9/1087.full.html\#ref-list-1

\section{License}

Email Alerting Service

http://genesdev.cshlp.org/content/suppl/2006/04/17/gad.1381906.DC1 right corner of the article or click here.

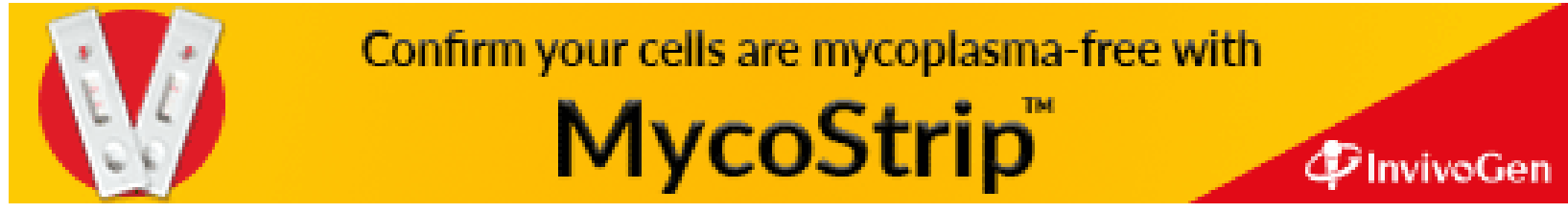

